\title{
Analysis of Vertebral Model in College Ideological and Political Education
}

\author{
${ }^{1, a}$ Sun $\mathrm{Yi}$ \\ ${ }^{1}$ Qingdao Vocational and Technical College of Hotel Management, Qingdao, Shandong 266000, \\ China \\ asqxcy_xue@126.com
}

Keywords: Vertebral model; ideological and political education; innovation; culture

\begin{abstract}
By regarding university teachers, college students and communication scientific research groups as the vertebral model, the paper analyzed innovation patterns and methods in current college ideological and political education. We can construct three educational cardinal lines from ideological and cultural education, exertion of subject competence and soft power of teachers to constitute a plane of educational contents. By considering teachers in colleges and universities as supporting points and regarding connection points between supporting points and the plane as communication scientific research groups, we can structure a management mode that conforms to college ideological and political education system, so as to improve ideological and political level of students.
\end{abstract}

\section{Introduction}

College ideological and political education returns to real life, which not only is a kind of value return, but also presents the vitality of ideological and political education [1, 2]. Ideological and political education of contemporary university students is being impacted by multiple aspects of a broad range of Internet, flood of entertainment, outspread mainstream ideology, far-flung cultural inferiority mentality and all kinds of social negative phenomena, etc., which dispel the effectiveness of ideological and political education of contemporary university students, and damage the world view, outlook on life and value conception system of college students, objectively. Such an objective reality needs college ideological and political educators to analyze confronting problems comprehensively, study causes of problems in depth and spare no efforts to explore approaches to promote effectiveness of ideological and political education of contemporary university students.

It is necessary to conduct reflection and dialectical inspection rationally on current situation of ideological and political education of contemporary university students [3, 4]. At present, on the macro level of ideological and political education of contemporary university students, there are still some problems, such as "hysteresis quality of education", "unidirectional management”, "political mode" and "infusion of teaching", etc. From the perspective of practical work in colleges and universities, there is the problem of attaching importance at the meeting, but ignoring of it after the meeting. From the perspective of educational research on ideological and political education of contemporary university students, there are problems of researching more subjects of education, but researching less objects of education and mediators of education, researching more external environmental changes by researchers and educational executors, but putting forward less feasible solutions by them. Carrier forms of ideological and political education include language carrier and action carrier, traditional carrier and modern carrier. Ideological and political education has three major development trends of characteristic, modernization, socialization, standardization and internationalization [5]. Most of researches lay a particular emphasis on exploring realization approaches to effectiveness of ideological and political education of contemporary university students or paying attention to definition of related notion and relationship research, but there is no comprehensive, systematic and in-depth research system. There is no attention to micro-factors within the macro vision. There is no multidisciplinary comprehensive analysis in theory. Or there is no feasible practice system. 
Based on analyzing and concluding ideological characteristics of college students and main contents of ideological and political education, the paper constructs an innovation pattern of college ideological and political education: the vertebral model of ideological and political education, which can constitute a plane of educational contents from ideological and cultural education, exertion of subject competence and soft power of teachers. By considering main strength of university teachers as a summit and regarding the connection position between a summit and the plane as a radiation platform of forming students' scientific research groups, we can promote ideological and political education of college students and improve its effectiveness and pertinence.

\section{Vertebral Model of Innovation Patterns in Ideological and Political Education}

Communication behaviors of college students appear a series of new characteristics, which mainly reflect in the individuation and diversification of communication subjects, decentralization and indirection of interactions, direction and convenience of communication behaviors, globalization of communication fields, virtualization of communication roles, bilateral interaction or multi-directional interaction of communication information carriers, etc. No matter it is in real world or in virtual space, college students dare to present the existence of their own value, blaze new trails in a pioneering spirit, dare to speak and date to act, have stronger performance desire. It is a great progress in society. However, because current information society has not formed complete and effective legal normative system yet, all kinds of information garbage on the Internet will weaken its morality and sense of duty. Information behaviors of information agents mainly depend on their automaticity and sense of moral responsibility. As a result, the original intention of surfing the Internet for most of students is to enjoy achievements created by modern science and technology, while weak normalization of virtual network causes weak morality. Thus, a part of students don't hesitate to damage benefits of the nation and others for satisfying individual stimulation, which is a moral disorder behavior. Elusive and anonymity of information network life display individuality and freedom of information individuals, but often weaken basic requirements of traditional moral rules. Therefore, randomness of individual behaviors is caused. It also encourages the deep-rooted bad habits in humanity to some extent. In virtual society, for college students, who are still in the growth stage of outlook on life, value and world view, it is easier to generate conflicts between their thought and reality.

How to implement contents of ideological and political education requires for understanding and grasping three important dimensionalities in college education, including educators (university teachers), educatees (college students) and education teams (learning scientific research groups). Meanwhile, these three dimensionalities should be conducted scientific allocation with educational contents. Thus, an educational model: the vertebral model of college ideological and political education is proposed, attempting to carry forward college ideological and political education more effectively.

Figure 1 shows the diagram of this vertebral mode. Three points of A, B and C represent three parts of main contents of ideological and political education of university students, respectively, namely cultivation of personality, occupation planning and interpersonal dimension. The plane ABC represents three parts of ideological and political education accepted by educatees (college students) are connected and supported mutually. V stands for educators (university teachers). The highest point implies that it holds a dominant position in ideological and political education of college students. Three planes of VAB, VAC and VBC mean that university teachers radiate contents of ideological and political education to the platform of college students, respectively. By constructing platform, university teachers permeate contents of ideological and political education into college students, while principal operators of this platform are education teams (learning scientific research groups). In learning and life process of colleges and universities, three kinds of crowds constitute important components of its growth, namely college students, university teachers, or those students who have the same discipline orientation background or elder and younger brothers with the same major.

These three dimensionalities of the designed vertebral model in ideological and political education of college students are drawn on the basis of it. These three dimensionalities involve in educators 
(university teachers), educatees (college students) and education teams (learning scientific research groups). Educatees (college students) hold a dominant position in vertebral model, are practicer and ultimate beneficiaries of three parts of educational contents, including ideological and cultural education, exertion of subject competence and soft power of teachers. Educators (university teachers) are direct administrators of cultivating college students. In the process of cultivating college students, they not only educate students with their scientific and cultural knowledge, but also cultivate students with noble ideology and morality. They take a leading role in ideological and political education of college students. Education teams (learning scientific research groups) are not student self-organizations in traditional significance, but are student groups who have a certain common research object and scientific research content based on establishing the same discipline orientation or the same university teacher. Learning scientific research groups play a bridge and bond role on vertebral mode, while their members are builders of atmosphere of ideological and political education, creators of ideological and political education forms, and organizers of ideological and political education activities. Existence of education teams makes connections between educators and educatees become more closely. Moreover, communication between them is more frequent and unhindered.

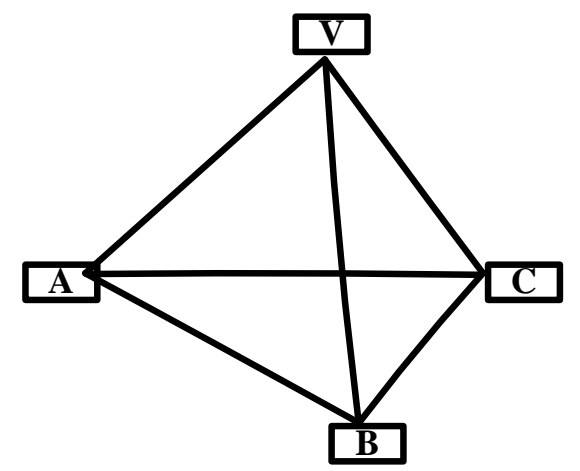

\author{
V said Education (University \\ Teachers), planar ABC said three parts \\ of College Students' Ideological \\ Education of cultivation of personality, \\ A said, B said college students \\ occupation planning, $C$ said the \\ interpersonal dimension
}

Figure 1 Diagram of Vertebral Model in College Ideological and Political Education

\title{
Analysis on Applicability of Vertebral Model of Ideological and Political Education in College Ideological and Political Education
}

Enhance Cultural Connotations of College Ideological and Political Education:Ideological and political education has class nature, but is confined to the political educational pattern. Excessive emphases on social value and instrumental motivation of ideological and political education, but regardless of students' practical needs and sitting pontificating of breaking away from life reality just result in separation between college ideological and political education of student life. Utterance of ideological and political education enters into the "unhindered" to a certain degree. On the contrary, integrity of ideological and political education enlarges ideological and political education contents wantonly, which will only result in formalization, generalization and vulgarization of college ideological and political education. The scarcity of cultural connotations in ideological and political education itself will cause the dislocation between college ideological and political education and demands of college students.

As shown in Figure 2, the college ideological and political education content, as an important component of culture, reflects the core value of culture. Educational process turns to educational methods and carriers of culture. Its essence is not only the cultural communication process, the process of educating people with culture and arranging for spirit, but also the process of promoting all-round development of human being. It possesses a significant cultural function and cultural mission. Cultural connotations of ideological and political education must excavate sufficiently and take advantage of abundant cultural factors contained in teaching materials of ideological and political theory. The socialist core value system is an essential expression of contemporary Chinese socialist ideology and is a quintessence of an advanced socialist culture. It is necessary to dig out cultural connotations in socialist core value system, realize cultural connotations between Marxist 
theory and Marxism with Chinese characteristics, guide ideological trend and build consensus by using socialist core value system, make it more close to reality, life and students, and increase cultural vitality for carrying out ideological and political education in a deep-going way.

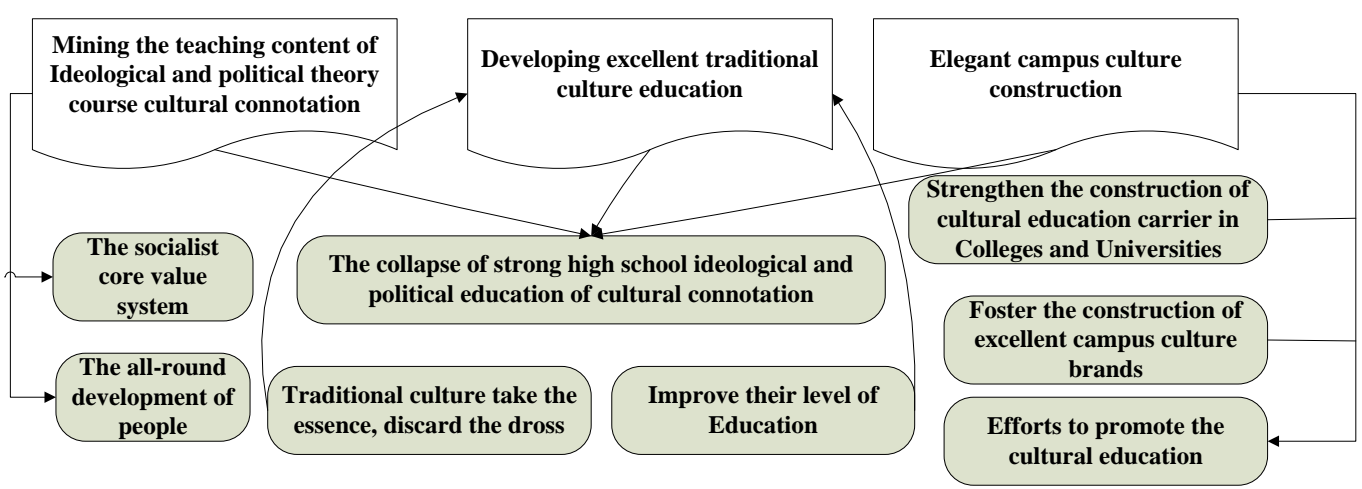

Figure 2 Enhanced Mode of College Ideological and Political Education and Culture

The teaching of college ideological and political theory course brings in excellent and traditional culture education, cultivates college students' interests and hobbies in traditional culture, combine excellent and traditional culture with noble sentiment, guide college students to read books concerning Chinese excellent and traditional culture, seek roots and trace to the source and learn traditional virtues of Chinese ethnic people. By making use of modern network technology, the ideological and political education website with the characteristic of rich Chinese excellent and traditional cultural contents is constructed, so as to make educational contents of traditional culture become concrete from the abstraction, become amusing from baldness and become popular from profoundness. "Teachers should cultivate people and solve their problems.” Ideological and political educators should improve their accomplishment and quality constantly by virtue of teaching traditional culture, enhance their educational level, develop and utilize excellent cultural resources, inherit Chinese civilization and achieve the goal of ideological and political education better.

Campus culture is the mental environment and cultural atmosphere owned by the school. It not only contains campus buildings, landscapes, and greening, etc. contents of materialized forms, but also involves in school tradition, school spirit, style of study and public opinion, etc. spiritual culture, and system culture of school rules and regulations. Positive, sound and elegant campus culture makes for cultivating students' sentiment, enlightening their mental, shaping their independent personality and promoting their development. Moreover, it can provide harmonious environment and atmosphere for cultivating college students with harmonious humanity through ideological and political education.

Play Subject Ability of College Students' Ideological and Political Education:In order to play the dominant role of college students in ideological and political education, university teachers possess an irreplaceable advantage in ideological and political education work of college students. However, no matter how important it is, it can't replace the college students themselves and become the subject of ideological and political education. Therefore, in practical application, it must further promote initiative of college students, make them realize the significance of ideological and political education, comprehend three parts of educational contents of the cultivation of personality, occupation planning and interpersonal dimension, and create mechanism to guide them to take delight in participation and tasting growth constantly. Main tasks of college students in this process are as follows three points: first of all it is necessary to learn from university teachers with an open mind and initiative, communicate with university teachers positively, and accept unconscious influences of university teachers' personal charisma and character and self-restraint, while promoting academic and scientific research ability. Secondly, it is necessary to blend in learning scientific research groups initiatively, constantly promote the ability to think independently in the learning and communication with friends, and spare no effort to arrange future career development. Thirdly, it is necessary to participate in interpersonal social integration education rationally. At present, social practices and part-time jobs are ways of interpersonal social integration adopted by college students generally. Nevertheless, we should take part in practical experience activities that are beneficial to 
personal growth, on the premise of no influences on school work and with the purpose of career development, improve ideological and political quality and cultivate harmonious college students. Fundamentally, all of these hang on students' self-education. College ideological and political education should lead students to realize themselves and evaluate themselves objectively and comprehensively, know about their advantages, dare to recognize their insufficiency, change their evil ways and reform, enhance self-discipline constantly and improve themselves through introspection, reflection and self0remounlding.

Enhance Soft Power Construction of Teachers in Ideological and Political Theory Course:In factors of influencing ideological and political education's effects of college students, the own factor of ideological and political educators is the most important factor of affecting ideological and political education's effects. In order to reinforce ideological and political theory course's construction of teaching staff, improve the actual effect of ideological and political theory course, it must enhance ideological and political theory course's soft power of teachers. The key is to promote personality charm of ideological and political theory course's teachers and emit charming atmosphere with attraction, infection and persuasion. Personality charm of ideological and political theory course's teachers lays a foundation on footstone of its inherent abundant connotations for teachers. Their natural emission in character, temperament, ability, moral character and manner, etc. can attract students and make them generate emotion of admiration, so as to let students accept unique strength sincerely guided by teachers' education. People with higher knowledge can be a teacher, and people with good conduct can be a standard. Therefore, ideological and political theory course's teachers should make efforts to improve their personality charm.

(1) Have positive and health psychology. The work engaged by college ideological and political educators is to be responsible for psychology and thought of college students. Just think about it, if ideological and political educators have passive attitude and psychological problems and are short of positive and health psychology, how can them undertake the teaching tasks and complete ideological work of college students. College ideological and political educators should be equipped with extensive and stable interests, abundant and health emotions, firm and decisive willpower, temperament with abundant connotations and good character.

(2) Have firm Marxism ideal and faith. Our ideological and political education is the Marxism ideological and political education, which is our subject attribute and subject characteristic. College ideological and political theory course's teachers must have firm ideal and faith of communism, insist in correct political stand, and have higher political level and understanding of policy. Their knowledge and action should go hand in hand, and suit the action to the word.

(2) Have excellent moral character. Ideological and political theory course's teachers, as the engineers of shaping college students' spirit, must have noble moral character and good professional moral accomplishment. Only they possess great moral sentiment can realize the ideological and political education's effect that silence is better than cry" and increase attraction and infection of ideological and political education.

(4) Have international horizon and the idea of modern education. Facing to international development, ideological and political education should cultivate the ability to distinguish, attract and boycott international cultural trend for college students, enhance national centripetal force, adjust psychology, adapt to international social development ability, prevent and resist emergent value belief crisis, spirit vulgarization, morality undone and passive and decadent life, etc. world problems.

(5) Have professional quality in ideological and political theory. The subject of ideological and political education should rely on the Marxist theory. Therefore ideological and political educators must have systematic theoretical knowledge of Marxism and professional knowledge of ideological and political education, reinforce consciousness of the subject constantly and promote professional quality, read education science, ethics, psychology, philosophy, politics, and aesthetics, etc. knowledge cursorily and simultaneously, absorb nourishment extensively, and combine fair persuasion with emotions, so as to make college ideological and political education become more vivid, lively and abundant and realize the essence of educating people by ideological and political education, indeed. 


\section{Conclusions}

Based on the vertebral model and by creating college ideological and political education, the paper explores and cultivates good patterns and innovation manners of ideological and political education of college students, and cultivates college students with harmonious humanity. College ideological and political educators should update educational ideas, enhance cultural connotations of college ideological and political education, carry forward content system optimization of college ideological and political education, create approaches and methods of college ideological and political education, construct harmonious environment for college ideological and political education, reinforce their soft power construction and promote ideological and political education of postgraduates to improve effectiveness and pertinence.

\section{References}

[1] Xie Xiaojuan, Five Changes in Work Idea of College Ideological and Political Education since the Reform and Opening-up Policy [J]. Ideological and Political Education Research, 2009, (25):3.

[2] Zhou Xunying, Vertebral Model: Research on Ideological and Political Education Innovation Patterns of Postgraduates [J]. Beijing: Studies in Ideological Education, 2014, 2:84-86.

[3] Tan Jingsong, Improvement of Effectiveness for Ideological and Political Education by Grasping Characteristics of Postgraduates [J]. Studies in Ideological Education, 2010, (3): 118-119.

[4] Zheng Jiana, Confronting Challenges and Countermeasures on Political Socialization of College Students in Period of Social Transition [J].Journal of Yunan Socialism College, 2013, (1):18-22.

[5] Zhang Jun, Power Generation of Modern Ideological and Political Education under New Media Environment [J]. School Party Construction and Ideological Education, 2011, 07: 18-22.

[6] Qian Yuanliang, Discussion on Theory and Reform of Human Self-Interest Assumption as the Logical Starting Point of Constructing Morality and Ethics, 2012, (02):30-34.

[7] Xing Pengfei and Cui Yongjian, Traditional Culture Approaches to Create College Ideological and Political Education [J]. China Newspaper Industry, 2012, (20):18-21.

[8] Zhang Yaocan, Re-examination on "Principles of Ideological and Political Education [J]. School Party Construction and Ideological Education, 2011, (28):10-14.

[9] Zeng Linghui, Soft Power Construction on Teacher Troop of College Ideological and Political Theory Course [J]. Theoretical Front in Higher Education, 2012,(03):51-53. 